\title{
Erratum: Regulation of interferon gamma signaling by suppressors of cytokine signaling and regulatory $\top$ cells
}

\section{Joseph Larkin III *, Chulbul M. Ahmed, Tenisha D. Wilson and Howard M. Johnson}

Department of Microbiology and Cell Science, University of Florida, Gainesville, FL, USA

${ }^{*}$ Correspondence: jlarkin3@ufl.edu

\section{Edited and reviewed by:}

Lee Mark Wetzler, Boston University School of Medicine, USA

\section{An erratum on}

Regulation of interferon gamma signaling by suppressors of cytokine signaling and regulatory $\mathrm{T}$ cells

by Larkin J III, Ahmed CM, Wilson TD and Johnson HM (2013). Front. Immunol. 4:469. doi:10.3389/fimmu.2013.00469

\section{ACKNOWLEDGMENTS}

The author's own work is supported by a grant from the Lupus Research Institute (Joseph Larkin III), NIH grants R01NS051245 and R01AI056152 (to Howard M. Johnson), a diversity supplement awarded to parent grant R01AI056152, a BD Biosciences Research Grant, the NIH/NCATS Clinical and Translational Science Awards to the University of Florida TL1 TR000066 and UL1 TR000064, and the University of Florida.

Received: 14 February 2014; accepted: 19 February 2014; published online: 04 March 2014.

Citation: Larkin J III, Ahmed CM, Wilson TD and Johnson HM (2014) Erratum: Regulation of interferon gamma signaling by suppressors of cytokine signaling and regulatory $T$ cells. Front. Immunol. 5:88. doi: 10.3389/fimmu. 2014.00088

This article was submitted to Immunotherapies and Vaccines, a section of the journal Frontiers in Immunology. Copyright $\odot 2014$ Larkin III, Ahmed, Wilson and Johnson. This is an open-access article distributed under the terms of the Creative Commons Attribution License (CC BY). The use, distribution or reproduction in other forums is permitted, provided the original author(s) or licensor are credited and that the original publication in this journal is cited, in accordance with accepted academic practice. No use, distribution or reproduction is permitted which does not comply with these terms. 